\title{
Investigation of Aggression and Emotional Intelligence Characteristics of the Students from Faculty of Sport Sciences and State Conservatory of Turkish Music
}

\author{
İbrahim Dalbudak ${ }^{1} \&$ Serkan Çelik $^{2}$ \\ ${ }^{1}$ Atabey Vocational School, Isparta University of Applied Sciences, Isparta, Turkey \\ ${ }^{2}$ Faculty of Tourism, University of Kâtip Çelebi, İzmir, Turkey \\ Correspondence: İbrahim Dalbudak, Atabey Vocational School, Isparta University of Applied Sciences, Isparta, \\ Turkey.
}

Received: April 15, 2019

doi:10.5539/ies.v12n9p117
Accepted: June 13, $2019 \quad$ Online Published: August 29, 2019

URL: https://doi.org/10.5539/ies.v12n9p117

\begin{abstract}
This study was performed to investigate the characteristics of emotional intelligence and aggression between the students from Ege University Faculty of Sport Sciences and the students from the State Conservatory of Turkish Music. A total of 211 people (top-tier athletes and top-tier artists from Ege University) were selected for the study. Questionnaire method was used in the study. To evaluate the variables of the study, the revised Schutte Emotional Intelligence Scale that was adapted to Turkish by Tatar, Tok, and Saltukoğlu which consists of 41 items and the "Inventory of Aggression" that was developed by İpek İlter (Kiper) which consists of 30 items was used. In this study, the data set was analyzed in the package program SPSS 22.0 and the study was done using frequency tables, reliability analysis, unpaired t-test, one-way analysis of variance, Tukey's test, and correlation analysis in the analyses. As a result, while a significant positive relationship between the emotional intelligence and the destructive and passive aggression was found $(\mathrm{p}<0.05)$, an insignificant negative relationship between the emotional intelligence and assertiveness was revealed ( $p>0.05$ ). We think that this is an important study because it helps us to be informed about the emotional intelligence and the aggression characteristics of the conservatory and sports sciences students and to make a serious contribution to the studies by conducting similar researches with different sample groups in different fields and different branches in different universities.
\end{abstract}

Keywords: faculty of sport sciences, state conservatory of Turkish music, emotional intelligence, aggression

\section{Introduction}

One of the most important factors affecting personality is emotional intelligence. Boyatzis, Goleman, and Rhee (2000) define the emotional intelligence as follows: "Emotional intelligence is observed when a person demonstrates the competencies that constitute self-awareness, self-management, social awareness, and social skills at appropriate times and ways in sufficient frequency to be effective in the situation". In contrast to the mixed model, which argues that emotional intelligence is a combination of character and state properties, the emotional intelligence ability model conceptualizes this structure as a set of skills (e.g. situations) that can be fully learned and developed over time. In a groundbreaking study on this subject, the emotional intelligence is defined as "A set of skills hypothesized to contribute to the accurate appraisal and expression of emotion in oneself and in others, the effective regulation of emotion in self and others, and the use of feelings to motivate, plan, and achieve in one's life" (Salovey \& Mayer, 1990).

Aggression is one of the important factors that greatly affect a person's performance. Human aggression has a psychological and social process with cases such as obtaining wealth, possessions, land, etc., showing one's self-improvement to the society, and overrating oneself. In order to realize these goals, one will damage the opposition physically or psychologically. Aggression is any behavior that aims to harm another verbally, physically, or implicitly (Kesen et al., 2007). Çobanoğlu (2005) described it as "Rather than a reaction to external stimuli, it is a stimulus that is trying to be free from the confines of the body and will find and expression regardless of the adequacy of external stimuli.

Sport is a phenomenon that contributes to the improvement of the mental health of the people, the formation of the personality and the development of the characteristic properties; enriches the knowledge and skills and facilitates 
the adaptation of the individual to his/her environment (Keskin, 2015). Scientific research has shown that doing sports regularly keeps people away from many physical discomforts, especially heart and vascular disorders, in addition to a proper physical appearance. In addition, it is said that sports are effective in eliminating the negative energy accumulated in the human body and in the prevention of stress, anger, aggression, and violence that this negative energy can create (Şenyüzlü, 2013).

The artistic values that first emerged with the rise of human are music, dance (Koçkar, 1990) and musical instruments. According to Hugel et al. (1999), dance is a specific expression of human motor behavior. According to Aktaş (1999), "dancing is the physical and emotional behavior that is the result of creativity with an aesthetic and rhythmic characteristic created by a collection of meaningful movements in order for a person to express his own feelings and thoughts and communicate with the society.". Dance is a phenomenon that the human body performs by spending energy in space and in time and arising from the relations of these elements with each other. Dance is in relation to five elements. These elements are the time, place, space, energy, and bodily awarenesses. These five basic factors of dance are the basis of all teachings of dance (McCutchen, 2006). The elements of dance are the center of dance work. The dancer always uses these dynamics in time and space (Board of Studies, 2003). A musical instrument is a device built to create musical sounds and have a specific form, usage and resonance properties (Say, 2001). Instrument training is a set of methods for playing an instrument. The main objectives of the instrument training are to teach the students to play the instrument with an accurate technique, to adjust the working time in a way to increase the efficiency, to comprehend the musical cultures through their instruments and to improve their musical skills (Parasiz, 2009). Music is an aesthetic whole composed of sounds combined with a certain purpose and method, processed according to a certain beauty concept (Uçan, 1994). Musical training, as well as musical instrument and dance training, develops the child emotionally and mentally, increases his/her ability to perceive, strengthens the imagination and memory, and contributes to the formation of his personality. Music, musical instruments, and dance training help to develop many features of humans. These features are the values that provide the individual with knowledge, skills, habits, and thought patterns within the training process (Demirova, 2008). In fact, education is the most obvious tool for developing societies (Yaşar, 2017).

Dance, music and musical instruments are closely related to sports. Because they are closely related, emotional intelligence and aggression sub-dimensions' students of sport sciences and conservatory show similarities. Even if there are similarities there are also some differences. For example, in dance works, the music that accompanies the movements reveal a difference that isolates dance from other sports by making a big contribution to breathing, heart rate, physical strength, endurance, learning of the basic motor skills and aerobic fitness (Bakioğlu, 2012).

Because the notions of emotional intelligence and aggression affect human life significantly, the aim of this study is the effort to find the necessary knowledge with necessary studies to better understand the human structure. This study was conducted to investigate the sub-dimensions of emotional intelligence and aggression of the university students of sports sciences and conservatory and in this domain, to determine the role of people involved in sports, music, dance, and musical instruments in emotional intelligence and aggression.

\section{Material and Method}

The acquisition of the data consists of three sections: emotional intelligence scale, aggression scale, and "Personal Information Form" that was created by the researcher in order to obtain demographic properties. The first section is the personal information form (gender, age, department, level of income) of the students.

In the second section, the "Adaptation of the revised Schutte emotional intelligence scale into Turkish and examination of its psychometric properties" was used that is the Schutte Emotional Intelligence Scale which consists of 41 items. The test includes an evaluation scale with items that increase from 1 to 5, meaning: "Strongly Disagree $=1$, Disagree $=2$, Neutral Minded=3, Agree=4, Strongly Agree $=5$ " (Tatar, Tok, \& Saltukoğlu, 2011). With this design, item-total values correlations and Cronbach's alpha internal consistency coefficients were calculated. According to the results, the scale's Cronbach's alpha internal consistency coefficient is 0.87 . The internal consistency coefficient of the original scale was found to be 0.85 by Austin et al. (2004) from a 500-person sample with a revised 41-item study. According to the study reported by Austin et al. (2004), the scale's internal consistency coefficients differ between 0.66 and 0.90 based on various studies by various researchers. The sub-dimensions of the Schutte Emotional Intelligence Scale consist of these items: Optimism/Regulation of Mood: 21, 25, 37, 18, 38, 30, 27, 29, 19, 33, 31, 7, 36, 9, 2, 11, 16, 5, 15, 1, 32; Evaluation of Emotions: 22, 40, 6, 17, 39, 35, 8, 24, 26, 3, 41, 28, 12; Use of Emotions: 34, 13, 14, 10, 4, 20, 23. According to the reliability analysis concerning the scale, the alpha value was calculated to be 0.64 (Tok, 2008).

In the third section, "Aggression Inventory" (Kiper 1984) developed by İpek İlter (Kiper) and personal information form developed by the researcher were used as a data collection tool. The aggression inventory 
developed by İpek İLTER (Kiper) in 1984 consists of 30 items and includes three subtests. These are destructive aggression, assertiveness, and passive aggression. Each sub-test in the inventory was identified with 10 questions. Items related to destructive aggression: 1, 2, 3, 13, 14, 15, 22, 23, 24, 29; Items related to assertiveness; 4, 5, 6, $10,11,12,19,20,21,28$; Items related to passive aggression: 7, 8, 9, 16, 17, 18, 25, 26, 27, 30. The materials used in the inventory are the questionnaire and the answer sheet. The questions are the type of 7-point Likert scale consisting of "does not suit me at all=-3", "does not suit me mildly=-2", "does not suit me=-1", "neutral=0", "suits $m e=+1$ ", "suits me mildly $=+2$ ", and "suits me strongly $=+3$ ".

The following table shows the Cronbach's alpha coefficients.

Table 1. The Cronbach's alpha coefficients

\begin{tabular}{lc}
\hline & Cronbach's Alpha \\
\hline Aggression Scale & 0.821 \\
Destructive Aggression & 0.782 \\
Assertiveness & 0.800 \\
Passive Aggression & 0.763 \\
Total Emotional Intelligence & 0.708 \\
\hline
\end{tabular}

Accordingly, it is observed that the reliability levels of the scales and their sub-dimensions are sufficient.

\subsection{Statistical Analysis}

In this study, the data set obtained through the questionnaire was analyzed in the package program SPSS 22.0 and the study was done using frequency tables, reliability analysis, unpaired t-test, one-way analysis of variance, Tukey's test, and correlation analysis in the analyses.

\subsection{Findings}

This study was conducted with a sample that was a group of students of the Faculty of Sport Sciences and State Conservatory of Turkish Music from Ege University. A total of 211 voluntary individuals participated in the study. Having a sufficient number of elite athletes and artists was effective in the selection of the Faculty of Sport Sciences and the State Conservatory of Turkish Music of Ege University. With the athletes, the Departments of Voice Training, Turkish Folklore Dance, and Music Fundamentals are situated in the study.

Table 2. The distribution of demographic information of the participants

\begin{tabular}{lccc}
\hline & & $\mathrm{n}$ & $\%$ \\
\hline \multirow{4}{*}{ Age } & $19-22$ & 85 & 40.3 \\
& $23-27$ & 82 & 38.9 \\
& above 28 & 44 & 20.9 \\
Gender & Total & 211 & 100.0 \\
\hline \multirow{4}{*}{ Department } & Male & 149 & 70.6 \\
& Female & 62 & 29.4 \\
& Total & 211 & 100.0 \\
\hline \multirow{3}{*}{ Level of Income } & Conservatory & 106 & 50.2 \\
& Total & 211 & 100.0 \\
\hline & $500-1000$ & 71 & 33.6 \\
& $1001-2000$ & 101 & 47.9 \\
& $2001-\ldots$ & 39 & 18.5 \\
& Total & 211 & 100.0 \\
\hline
\end{tabular}

The distribution of the demographic information of the participants was analyzed by frequency analysis and given in the table.

The distribution of the participants by age is shown in Figure 1. 


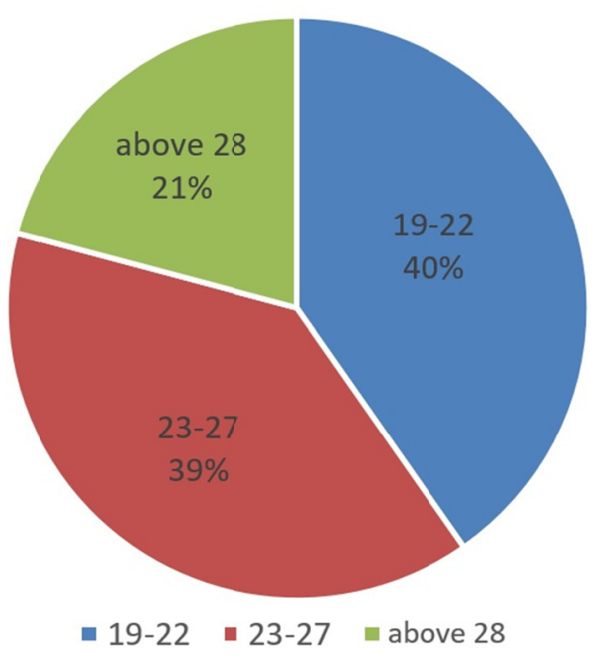

Figure 1. The distribution of the participants by age

The distribution of the participants by gender is shown in Figure 2 .

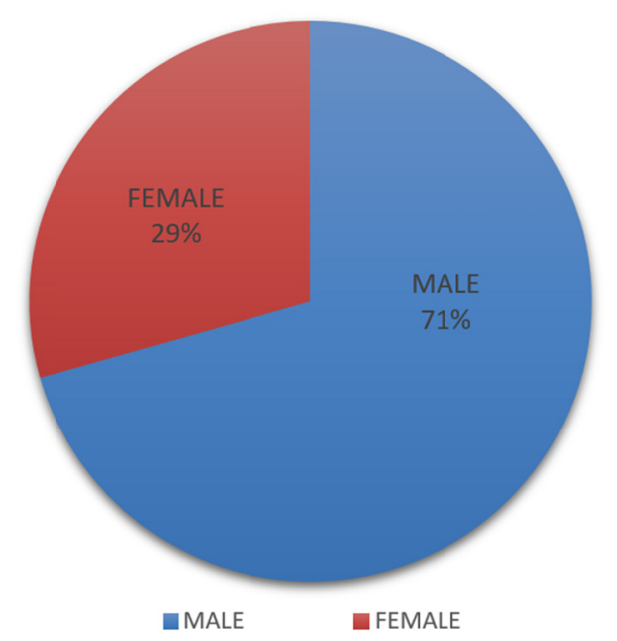

Figure 2. The distribution of the participants by gender

The distribution of the participants by department is shown in Figure 3. 


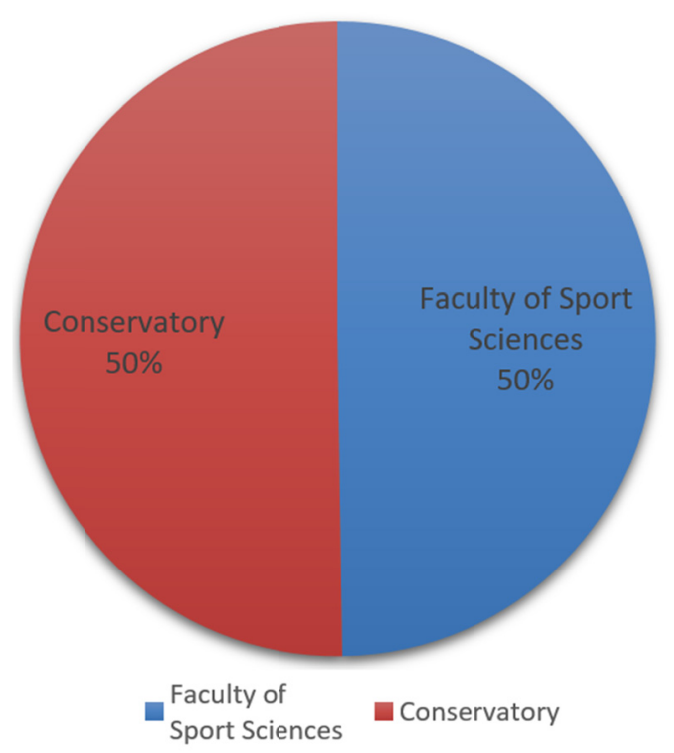

Figure 3. The distribution of the participants by department

The distribution of the participants by level of income is shown in Figure 4.

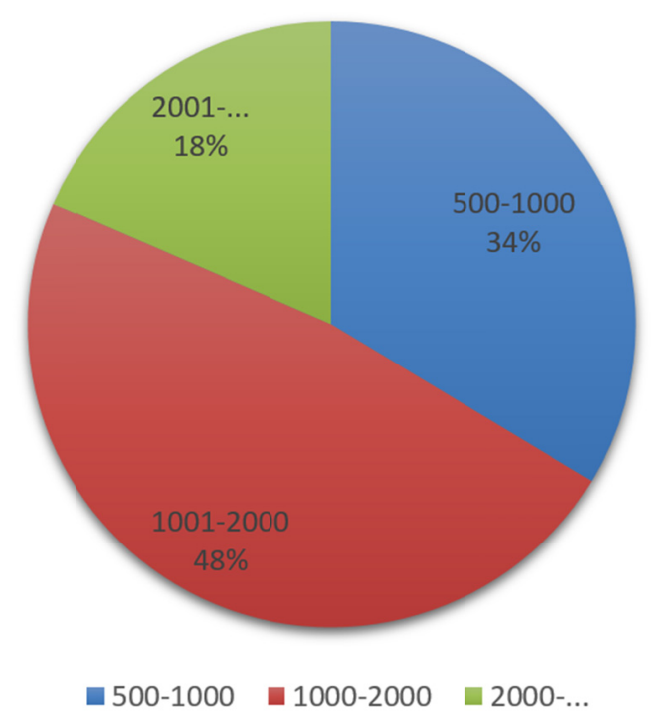

Figure 4. The distribution of the participants by level of income

\subsubsection{Variance of the Emotional Intelligence Scale According to Age Groups}

The means of the emotional intelligence scale's sub-dimensions according to age groups and the results of the one-way ANOVA that was done to detect whether the difference between these means are significant or not were given. 
Table 3. Variance of the emotional intelligence scale according to age groups

\begin{tabular}{cccccccc}
\hline & Age Groups & $\mathrm{n}$ & Mean & Standard Deviation & $\mathrm{F}$ & $\mathrm{p}$ & Difference \\
\hline & $19-22$ & 85 & 3.22 & 0.29 & & & $19-22$ \\
\multirow{5}{*}{ Total Emotional Intelligence } & $23-27$ & 82 & 3.11 & 0.20 & & & a.295 \\
& above 28 & 44 & 3,19 & 0.24 & & .014 & and \\
& Total & 211 & 3.17 & 0.25 & & & $23-27$ \\
\hline
\end{tabular}

$\mathrm{p}<0.05$.

It was concluded that the emotional intelligence scale showed significant difference $(F=4,395, p<0.05)$ by age; according to the results of the post-hoc test that was done in order to determine which age groups had this difference, age groups 19-22 and 23-27 were the ones and there was no difference between the other age groups. In other words, there is a significant difference between the emotional intelligence levels of the individuals of age groups 19-22 and 23-27.

\subsubsection{Variance of the Emotional Intelligence Scale According to Gender}

The means of the emotional intelligence level according to gender and the results of the unpaired t-test done in order to determine whether the differences between these means are significant or not were given.

Table 4. Variance of the emotional intelligence scale according to gender

\begin{tabular}{ccccccc}
\hline & Gender & $\mathrm{N}$ & Mean & Standard Deviation & $\mathrm{t}$ & $\mathrm{P}$ \\
\hline \multirow{2}{*}{ Total Emotional Intelligence } & Male & 149 & 3.16 & 0.26 & \multirow{2}{*}{1.125} & \multirow{2}{*}{0.262} \\
& Female & 62 & 3.20 & 0.22 & & \\
\hline
\end{tabular}

$* \mathrm{p}<0.05$.

The emotional intelligence scale does not show a significant difference according to gender $(t=-1.125, p>0.05)$.

2.2.3 Variance of the Emotional Intelligence Scale According to Level of Income

The means of the emotional intelligence level according to level of income and the results of the one-way ANOVA done in order to determine whether the differences between these means are significant or not were given.

Table 5. Variance of the emotional intelligence scale according to level of income

\begin{tabular}{ccccccc}
\hline & Level of Income & $\mathrm{N}$ & Mean & Standard Deviation & $\mathrm{F}$ & $\mathrm{p}$ \\
\hline & $500-1000$ & 71 & 3.22 & 0.31 & & \\
Total Emotional Intelligence & $1001-2000$ & 101 & 3.15 & 0.22 & & \\
& $2001-\ldots .$. & 39 & 3.15 & 0.21 & 1.819 & 0.155 \\
& Total & 211 & 3.17 & 0.25 & & \\
\hline
\end{tabular}

It was determined that the emotional intelligence scale did not show a significant difference according to level of income $(\mathrm{F}=1.819, \mathrm{p}>0.05)$.

\subsubsection{Variance of the Emotional Intelligence Scale According to Departments}

The means of the emotional intelligence level according to departments and the results of the unpaired t-test done in order to determine whether the differences between these means are significant or not were given.

Table 6. Variance of the emotional intelligence scale according to departments

\begin{tabular}{lcccccc}
\hline & Department & $\mathrm{N}$ & Mean & Standard Deviation & $\mathrm{t}$ & $\mathrm{P}$ \\
\hline \multirow{2}{*}{ Total Emotional Intelligence } & Faculty of Sport Sciences & 105 & 3.16 & 0.25 & \multirow{2}{*}{0.484} & \multirow{2}{*}{0.629} \\
\cline { 2 - 7 } & Conservatory & 106 & 3.18 & 0.26 & & \\
\cline { 2 - 6 }
\end{tabular}

$* \mathrm{p}>0.05$.

The emotional intelligence scale does not show a significant difference according to departments $(\mathrm{t}=-0.484$, 
$\mathrm{p}>0.05$ ). In other words, there is no difference in terms of emotional intelligence between the students of sport sciences and conservatory.

\subsubsection{Variance of the Aggression Scale According to Age Groups}

The means of the aggression scale's sub-dimensions according to age groups and the results of the one-way ANOVA that was done to detect whether the difference between these means are significant or not were given.

Table 7. Variance of the aggression scale according to age groups

\begin{tabular}{lccccccc}
\hline & Age Groups & $\mathrm{N}$ & Mean & Standard Deviation & $\mathrm{F}$ & $\mathrm{P}$ & Difference \\
\hline \multirow{5}{*}{ Destructive Aggression } & $19-22$ & 85 & 26.51 & 8.31 & & & \\
& $23-27$ & 82 & 23.07 & 6.68 & & & $19-22$ and 23-27 \\
& above 28 & 44 & 21.07 & 4.98 & 9.746 & .000 & $19-22$ and above 28 \\
& Total & 211 & 24.04 & 7.39 & & & \\
\hline \multirow{5}{*}{ Assertiveness } & $19-22$ & 85 & 38.59 & 5.96 & & & \\
& $23-27$ & 82 & 39.40 & 7.39 & & & \\
& above 28 & 44 & 37.57 & 7.34 & 1.047 & .353 & \\
\hline \multirow{5}{*}{ Passive Aggression } & Total & 211 & 38.69 & 6.84 & & & \\
& $19-22$ & 85 & 24.61 & 8.42 & & & \\
& $23-27$ & 82 & 21.91 & 6.72 & & & \\
& above 28 & 44 & 20.80 & 4.80 & 5.099 & .007 & $19-22$ and 23-27 and above 28 \\
& Total & 211 & 22.77 & 7.28 & & & \\
\hline
\end{tabular}

In the aggression scale, while there are significant differences on the sub-dimensions Destructive Aggression $(\mathrm{F}=9.746, \mathrm{p}<0.05)$ and Passive Aggression $(\mathrm{F}=5.099, \mathrm{p}<0.05)$, a significant difference was not found on the sub-dimension Assertiveness ( $\mathrm{F}=1.047, \mathrm{p}>0.05)$ according to age groups.

According to the results of the post-hoc test that was done in order to determine which age groups had differences, concerning the Destructive Aggression values, it was determined that there is a significant difference between the age groups 19-22 and 23-27, and 19-22 and above 28, but no significant difference between age groups 23-27 and above 28 .

In the same way, concerning the Passive Aggression values, it was determined that there is a significant difference between the age groups 19-22 and 23-27, and 19-22 and above 28, but no significant difference between age groups 23-27 and above 28 .

\subsubsection{Variance of the Aggression Scale According to Gender}

The means of the aggression scale's sub-dimensions according to gender and the results of the unpaired t-test done in order to determine whether the differences between these means are significant or not were given.

Table 8. Variance of the aggression scale according to gender

\begin{tabular}{lllllll}
\hline & Gender & $\mathrm{N}$ & Mean & Standard Deviation & $\mathrm{t}$ & $\mathrm{P}$ \\
\hline \multirow{3}{*}{ Destructive Aggression } & Male & 149 & 25.11 & 7.82 & \multirow{3}{*}{3.336} & 0.001 \\
& Female & 62 & 21.45 & 5.47 & & \\
\multirow{2}{*}{ Assertiveness } & Male & 149 & 38.58 & 6.84 & -0.365 & 0.723 \\
& Female & 62 & 38.95 & 6.88 & & \\
\multirow{2}{*}{ Passive Aggression } & Male & 149 & 23.74 & 7.66 & \multirow{2}{*}{3.062} & 0.002 \\
& Female & 62 & 20.44 & 5.67 & & \\
\hline
\end{tabular}

${ }^{*} \mathrm{p}<0.05$.

While there are significant differences on the sub-dimensions Destructive Aggression $(t=3.336, p<0.05)$ and Passive Aggression ( $\mathrm{t}=3.062, \mathrm{p}<0.05$ ), a significant difference was not found on the sub-dimension Assertiveness $(\mathrm{t}=-0.355, \mathrm{p}>0.05)$ according to gender. In other words, it can be said that males are more aggressive than females in terms of Destructive Aggression and Passive Aggression and there is no difference between males and females in terms of Assertiveness. 


\subsubsection{Variance of the Aggression Scale According to Department}

The means of the aggression scale's sub-dimensions according to departments and the results of the unpaired t-test done in order to determine whether the differences between these means are significant or not were given.

Table 9. variance of the aggression scale according to department

\begin{tabular}{lcccccc}
\hline & Department & $\mathrm{N}$ & Mean & Standard Deviation & $\mathrm{t}$ & $\mathrm{p}$ \\
\hline \multirow{2}{*}{ Destructive Aggression } & Faculty of Sport Sciences & 105 & 25.91 & 7.71 & \multirow{2}{*}{3.787} & 0.000 \\
& Conservatory & 106 & 22.18 & 6.58 & & \\
\multirow{2}{*}{ Assertiveness } & Faculty of Sport Sciences & 105 & 39.28 & 7.84 & \multirow{2}{*}{1.237} & 0.217 \\
\multirow{2}{*}{ Passive Aggression } & Conservatory & 106 & 38.11 & 5.66 & & \\
& Faculty of Sport Sciences & 105 & 23.70 & 8.21 & \multirow{2}{*}{1.872} & 0.063 \\
\hline
\end{tabular}

In the aggression scale, there is a significant difference on the sub-dimension Destructive Aggression $(t=3.787$, $\mathrm{p}<0.05)$ and there are no significant differences on the sub-dimensions Assertiveness $(t=1.237, p>0.05)$ and Passive Aggression $(t=1.872, p>0.05)$ according to departments. In other words, the students of sport sciences possess more destructive aggression than the students of the conservatory.

\subsubsection{Relationship Between the Aggression Scale and the Emotional Intelligence Scale}

In order to determine the relations between the sub-dimensions of the aggression scale and the emotional intelligence scale, correlation analysis was done and Pearson's correlation coefficient was obtained.

Table 10. Relationship between the aggression scale and the emotional intelligence scale

\begin{tabular}{llc}
\hline & & Total Emotional Intelligence \\
\hline Destructive Aggression & $\mathrm{R}$ & $.354^{* *}$ \\
& $\mathrm{P}$ & .000 \\
Assertiveness & $\mathrm{R}$ & .074 \\
& $\mathrm{P}$ & .287 \\
Passive Aggression & $\mathrm{R}$ & $.295^{* *}$ \\
& $\mathrm{P}$ & .000 \\
\hline
\end{tabular}

${ }^{* *} \mathrm{p}<0.001$.

According to this, there is a $35.4 \%$ significant positive relation between the emotional intelligence and the destructive aggression and a $29.5 \%$ significant positive relation between the emotional intelligence and the passive aggression $(\mathrm{p}<0.05)$. A significant relation was not found between emotional intelligence and assertiveness $(\mathrm{p}>0.05)$.

\section{Discussion and Result}

When the conservatory and sports science students at the university were investigated according to emotional intelligence and aggression characteristics, interesting results in terms of emotional intelligence and aggression were found in this study. In the light of the literature, these results will be questioned whether emotional intelligence and aggression can be useful variables in terms of sports psychology and whether the socio-psychological factors surrounding the sports environment cause a difference in the emotional intelligence and aggression characteristics of individuals. Also, in this section where the relationship between emotional intelligence and aggression will be discussed, in particular, the degree to which emotional intelligence overlaps with aggression will be examined.

The main aim of this study is to determine the role of emotional intelligence on aggression among students in sports science and conservatory. The aim is to determine whether there is a significant relationship between the levels of emotional intelligence and aggression in terms of demographic characteristics. This study was carried out with a total of 211 volunteer individuals, 149 males and 62 females, who are studying at Ege University, sport sciences and conservatory.

According to the results of the study; 
The overall emotional intelligence scale shows a significant difference in terms of age $(p<0.05)$. However, there is no significant difference between the emotional intelligence levels of the individuals of age groups 19-22 and 23-27. It was found that there was no difference between the other groups. Oğan and Toy (2017), Adiloğulları and Gencay (2016), and Halilbeyoğlu and Salman (2018) determined that there is no significant relationship between emotional intelligence and age factor. The fact that there was no difference on emotional intelligence between different age groups in the literature indicates that age is not effective on emotional intelligence and due to the fact that the participants were attending the same university and therefore being affected by the similar cultural aspects of that university, the participants' experienced similar feelings.

The overall emotional intelligence scale does not show a significant difference in terms of gender $(p>0.05)$. In the study, that was conducted using the same measuring method, by Tok (2008), there is no difference in emotional intelligence between genders. Schutte et al. (1998), Argyle (1994), and Harrod and Scheer (2005) found that the level of emotional intelligence of the females was significantly higher than the males'. Despite the various studies conducted show gender differences, this study's findings that show no difference between genders in terms of emotional intelligence that may indicate the participant students have mutual emotions, courses, exams, social opportunities, and are in communication with each other.

It was determined that the total emotional intelligence scale does not show a significant difference in terms of level of income ( $p>0.05$ ). Göçet (2006), Kahraman (2013), and Yılmaz and Şahin (2004) stated that there was no significant difference between level of income and emotional intelligence levels. Considering the studies done, we think that emotional intelligence is not related to the economic situation and materiality does not have an effect on emotional intelligence.

It was determined that the total emotional intelligence scale does not show a significant difference in terms of department ( $p>0.05)$. In other words, there is no difference between the students of sport sciences and conservatory in terms of emotional intelligence. In many studies, there is a significant difference between athletes and sedentary individuals. It was found that athletes' emotional intelligence levels were high. There was no significant difference between sports science students and conservatory students. Athletes and individuals in the conservatory also require the use of various physical and emotional skills. Many characteristics of athletes and individuals in the conservatory are similar. Athletes and conservatory students have similar experiences in many subjects such as group integrity, team communication, the effect of the audience, competition anxiety, use of physical characteristics and reasoning, being in the struggle against the opponent. The fact that the athletes and individuals in the conservatory have to manage their emotions in order to continue their behavior related to their fields indicates that the findings obtained from this study coincide.

It was determined that there is a significant difference between the age groups 19-22 and 23-27, and 19-22 and above 28 regarding the Destructive Aggression values $(\mathrm{p}<0.05)$, there was no significant difference between the age groups 23-27 and above 28 ( $>0.05$ ). Tekin et al. (2011) and Çakır (2014) stated that there is a significant difference between participants from different age groups in terms of destructive aggression. The primary goal in the destructive (hostile) aggression is to harm the other one, hurt their feelings. In other words, aggression which is hostile is a result in and of itself (Tiryaki, 2000). It was found that different age groups showed different destructive aggression values. It can be said that the reasons for this are extreme desire to win, extreme passion, not being able to handle defeat and social factors fueling this such as fans, trainers, and media.

There is no significant difference in the sub-dimensions of the assertiveness according to age groups $(\mathrm{p}>0.05)$. Hoşgör et al. (2016), Küçükkaragöz et al. (2013), and Tekin et al. (2011) revealed that there is no significant difference between age groups and the assertiveness. Yiğit et al. (2017) stated that assertiveness could be described as a kind of interpersonal relation that being able to protect one's rights without belittling others and being able to express one's feelings and thoughts clearly. Assertiveness does not mean aggression. Because humans are individuals and try to draw attention to their distinctness, prove themselves, be able to make requests from other individuals, being in communication with other humans, trying to prove that they can make a difference in the society may cause their assertiveness levels to differ.

It was determined that there is a significant difference between the age groups 19-22 and 23-27, and 19-22 and above 28 regarding the Passive Aggression values $(\mathrm{p}<0.05)$, there was no significant difference between the age groups 23-27 and above 28 (p>0.05). Tekin et al. (2011) and Çakır (2014) stated that there is a significant difference between participants from different age groups in terms of passive aggression. Passive aggression may occur in the form of extreme mocking and ridicule (Cengiz, 2004). The students of sport sciences and the conservatory from different age groups have different passive aggression values and this may be stemming from the sources such as the unethical discourse of managers, trainers, referees, media, fans, students' incontinence, 
students being uninformed and inexperienced, and unable to accept the defeat.

The destructive aggression that is one of the sub-dimensions of the aggression scale shows a significant difference in terms of gender $(\mathrm{p}<0.05)$. In other words, regarding the destructive aggression, males are more aggressive than females. This is consistent with the studies of Erşan et al. (2009) and Rainey (1984) that females have lower destructive aggression values than males and males having higher destructive aggression values than females. We think that males show their feelings explicitly as against females and because males reveal their feelings in a way of destructive aggression, males act aggressively due to their incontinence when they get angry. We think that due to gender roles, they take courage because they are males and get aggressive.

The assertiveness that is one of the sub-dimensions of the aggression scale does not show a significant difference in terms of gender ( $p>0.05)$. It can be said that there is no difference between males and females in terms of assertiveness. In the studies of Dalbudak (2012) and Erşan et al. (2009), it was determined that there was no significant difference between males and females in terms of the sub-dimension assertiveness. Kiper (1984) defined assertiveness as one's ability to express their feelings without worrying about their self-interests and any behavior that ensures the usage of one's rights while protecting others'. In assertiveness, while the individuals express their rights, feelings, and thoughts, they consider the others' rights. Whether it's a male or a female, the aim of them all is to use their minds and physical strength against their rivals. We believe that this is interpreted as assertiveness and playing by the rules is not considered as aggression but assertiveness.

The passive aggression that is one of the sub-dimensions of the aggression scale shows a significant difference in terms of gender $(p<0.05)$. In other words, it can be said that regarding passive aggression, males are more aggressive than females. This is consistent with the studies of Erden (2007) and Rainey (1984) that females have lower destructive aggression values than males and males having higher destructive aggression values than females. In our study, it can be said that males refer to indirect aggression that caused the values of passive behavior to appear high in males. The reason for passive behavior to occur may be because males tend to achieve superiority around themselves, get satisfaction from others' misfortunes, irritate their rivals verbally, convey their need to be strong, mean, and authoritarian. On the other hand, females having behaviors such as avoiding insulting and offensive statements, being sensitive towards others' needs, being tolerant towards others, being understanding, tolerant, and agreeable towards the society, restraining their feelings, not feeling the need to appear mean and authoritarian may have caused the females' passive behavior values to appear lower than the males.

The destructive aggression that is one of the sub-dimensions of the aggression scale shows a significant difference in terms of departments $(\mathrm{p}<0.05)$. In other words, the students of sport sciences are more aggressive than the students of conservatory regarding destructive aggression. Dalbudak (2012) and Tiryaki (2000) found that individuals who are doing sports display significantly more aggressive behavior than the individuals who are not doing sports. The reasons such as the need to prove oneself, make one's presence felt, the effect of the audience, and experiencing defeat may cause destructive behavior in the game. These may cause destructive aggression while expressing feelings in such a way by causing intentional physical harm to others. Having the goal to hurt others, harm them, or to see them get harmed may cause the values of destructive aggression to appear high. In the conservatory, immediate aggressive behaviors are not seen. There is face-to-face contact in sports. Factors such as rivals, fans, trainers, and referees may cause the athletes to display destructive aggression. This indicates that the destructive aggression is lower in athletes than the individuals in the conservatory that such factors are nonexistent.

Regarding the assertiveness, there is no significant difference in terms of departments ( $>0.05)$. There is no significant difference between the students of sport sciences and the students of the conservatory. Athletes using their minds and physical strength against their rivals within the rules of the game and the individuals of the conservatory signing the best song, doing the best folklore and dance show, playing the best instrument is considered assertiveness. We think that a boxer knocking out their opponent with a punch, dancers dancing in a different way, musicians playing an instrument and singing in a different way are defined as assertive. The reason why there is no significant difference between the departments indicates both departments have similar features.

Regarding the passive aggression, there is no significant difference in terms of departments $(p>0.05)$. Between the students of sport sciences and the students of the conservatory, a significant difference was not found. Passive aggression was defined as satisfying the emotion of aggression without making the others angry. Here, the desire to physically harm the others is repressed. Because the passive aggression is a type of passive behavior, engaging in a struggle is not acceptable. Passive aggression can be considered as sending harmful stimuli to others in an indirect way because it is an indirect kind of aggression. Passive aggression can be considered as an indirect aggressive behavior by being crossed with others, sulking, and indicating being sad and offended (Tutkun et al., 2010). We believe that the reason why there was no significant difference was found is because both of the departments 
satisfy their aggressive feelings by engaging their opponents indirectly without physical action.

There is a $35.4 \%$ significant positive relation between the total emotional intelligence and the destructive aggression and a $29.5 \%$ significant positive relation between the emotional intelligence and the passive aggression $(\mathrm{p}<0.05)$. Total emotional intelligence is inversely correlated with destructive and passive aggression. As the total emotional intelligence level increases, the destructive and passive aggressions decrease. The findings of the study coincide with the studies of Jaswant (2015) and Dalbudak et al. (2017). In the study conducted by Çelik (2017), the level of satisfaction of nursing services of patients increased as the emotional intelligence skills of nurses increased. Individuals who are able to use their emotional intelligence effectively are those who have empathy, have self-awareness, have strong social skills, have self-control and have a high level of motivation. These individuals approach the problems they face more positively and reach fast and effective solutions (Salovey \& Mayer, 1990). Aggression is one of the important factors that greatly affect a person's performance. Aggression is one of the important factors that significantly affect the performance of an individual. Aggression in man has psychological and social course with chief motive being control (acquisition of wealth, property, territory, etc.), increase (making the self, community and society grow in dimensions), and domination (showing oneself as stronger, more important, and more effective than others) (Jaswant \& Kultaj, 2015). In the literature, it is seen that aggression negatively affects the performance of individuals, and emotional intelligence positively affects the performance. There was no significant relationship between total emotional intelligence and assertiveness $(p>0.05)$. Total emotional intelligence is directly proportional to assertiveness. The findings of assertiveness contradict with the findings of Jaswant (2015) and Dalbudak et al. (2017). In spite of the widespread findings of differences regarding assertiveness in the literature, in this study, no significant relationship between the emotional intelligence and assertiveness, may be the indication of the possibility of assertiveness is affected by emotional intelligence. If it is a type of aggression, assertiveness should be declining. However, when we consider assertiveness as the ability of individuals to express their positive feelings, thoughts, and needs, it is understood that there is a positive relationship with emotional intelligence. It is understood that assertiveness can have qualities that will lead to a positive relationship with both emotional intelligence and aggression.

When the current literature and the results of this study are considered together, it is seen that new researches should be conducted with different methodologies and samples. In order to make generalizations by reaching clearer and more reliable results, it is advisable to do more research in different areas regarding emotional intelligence in our country.

\section{References}

Adiloğulları, G., \& Gencay, S. (2016). Examining of relation between emotional intelligence levels and professional burnout levels of Physical Education Teachers International Journal of Sport, Exercise \& Training Sciences, 2(1), 7-21. https://doi.org/10.18826/ijsets.67612

Aktaş, G. (1999). Temel Dans Eğitimi [Basic Dance Education ]. Ege University, Basım Evi, İzmir, Turkey.

Argyle, M. (1994). The psychology of interpersonal behaviour. Penguin, UK.

Austin, E. J., Saklofske, D. H., Huang, S. H., \& McKenney, D. (2004). Measurement of trait emotional intelligence: Testing and cross-validating a modified version of Schutte et al.'s (1998) measure. Personality and individual differences, 36(3), 555-562. https.//doi.org/10.1016/S0191-8869(03)00114-4

Bakığlu, Ç. (2012). Müzik Öğretmenliği Programı Öğrencileri İle Devlet Konservatuarı Müzik Bölümü Ögrencilerinin Piyano Çalgısına Yönelik Tutumlarının Karşllaştırılması[The comparison of attitudes between the students of piano instrument of the music education programme and students of State Conservatory Music Department] (Master thesis, Karadeniz Teknik University, Trabzon, Turkey).

Board of Studies. (2003). Dance Years 7-10 Syllabus (p. 16). Australia: Sydney.

Boyatzis, R. E., Goleman, D., \& Rhee, K. (2000). Clustering competence in emotional intelligence: Insights from the Emotional Competence Inventory (ECI). Handbook of emotional intelligence, 99(6), 343-362. Retrieved from http://www.eiconsortium.org/pdf/eci_acticle.pdf

Çakır, İ. H. (2014). Liseler Arası Müsabakalara Katılan Sporcu Öğrencilerin Saldırganlık Durumlarının Araşttrılması [Rize İli Örneği] [Research of aggressive states of student athlete participating inter high school competitions ] [the case of Rize city] (Master thesis, Dumlupınar University, Kütahya, Turkey).

Çelik, G. O. (2017). The relationship between patient satisfaction and emotional intelligence skills of nurses working in surgical clinics. Patient preference and adherence, $11,1363$. https.//doi.org/10.2147/PPA.S136185 
Cengiz, R. (2004). Futbol Antrenörlerinin Saldırganlık Türleri ve Şiddet Olaylarına Bakış Açıları[Types of aggression of football coaches and perspectives of violence] (Master thesis, Gazi University, Ankara, Turkey).

Çobanoğlu, Ş. (2005). Mobbing: İsyerinde duygusal saldırl ve mücadele yöntemleri[Mobbing: Emotional attack and struggle methods in the workplace]. Timaş Yayınları.

Dalbudak İ. (2012) 13-15 Yaş Arası Spor Yapan ve Yapmayan Görme Engelli Bireylerin Stres ve Saldırganlık Düzeylerinin Incelenmesi [The evaluation of stress and aggression levels of 13-15 years old aged visually impaired athletes] (Master thesis, Ege University, İzmir, Turkey).

Dalbudak, İ., Yiğit, M., S., Ramazanoğlu, F., Beyleroğlu, M., Gökyürek, B., \& Okan, İ. (2016) The analysıs of emotional intelligence and aggression levels of performance athletes in faculty of sports sciences and non-exerciser students in vocational school students [Isparta sample]. Journal of Physical Education and Sport Sciences, 18(4), 51-66. Retrieved from https://atauni.edu.tr/beden-egitimi-ve-spor-bilimleri-dergisi

Demirova, G. (2008). Piyano Eğitiminin İlköğretim Öğrencilerinin Dikkat Toplam Yetisine Etkisi[The impact of piano education on students concentration skill] (Doctoral dissertation, Ankara University, Eğitim Bilimleri Enstitüsü, Ankara, Turkey). Retrieved from http://acikarsiv.ankara.edu.tr/fulltext/4879.pdf

Erden, N. K. (2007). Abant İzzet Baysal Üniversitesi Öğretmenlik Bölümleri Birinci Öğretim Son Sinlf Ögrencilerinin Saldirganlık Türleri[Abant İzet Baysal University Department of Teacher Education The Types of Aggression] (Master thesis, Abant İzzet Baysal University, Bolu, Turkey).

Erşan, E., Dogan, O., \& Doğan, S. (2009). The evaluation from point of view sociodemographic variables of the levels of aggression in the students of College of Physical Education and Sports. Cumhuriyet Medical Journal (CMJ), 31(3), 231-238. Retrieved from http://dergipark.ulakbim.gov.tr/cumucmj

Göçet, E. (2006). Üniversite Öğrencilerinin Duygusal Zekâ Düzeyleri İle Stresle Başa Çıkma Tutumları Arasindaki İliski[The Relationship Between University Students' Emotional Intelligence Levels and Stress Coping Attitudes] (Master thesis, Sakarya University, Sakarya, Turkey).

Halilbeyoğlu, F. H., \& Salman, N. M. (2018). Examınıng the emotıonal intelligence levels of badmınton players according to some variables, Social Sciences Studies Journal (SSSjournal), 4(13), 242-248. https://doi.org/10.26449/sssj.254

Harrod, N. R., \& Scheer, S. D. (2005). An exploration of adolescent emotional intelligence in relation to demographic characteristics. Adolescence, 40(159), 503. Retrieved from https://www.ncbi.nlm.nih.gov/pubmed/16268129

Hoşgör, H., Kurtuluş, S. A., Hoşgör, D. G., \& Söyük, S. (2016). The determınatıon of assertıveness levels of university students: The case of the faculty of health sciences, The Journal of Academic Social Science, 4(32), 430-441. https://doi.org/10.16992/ASOS.3472

Hugel, F., Cadopi, M., Kohler, F., \& Perrin, P. H. (1999). Postural control of ballet dancers: A specific use of visual input for artistic purposes. International journal of sports medicine, 20(02), 86-92. https.//doi.org/10.1055/s-2007-971098

Jaswant, K. S. (2015). Correlation study of Aggression, Emotional Intelligence and Well-Being among Judo Players. International Journal of Enhanced Research in Educational Development, 26-30.

Kahraman, N. (2013). Hemşirelerin Duygusal Zekâ Becerilerinin Belirlenmesi,[Determination of Emotional Intelligence Skills of Nurses] (Master thesis, Hacettepe University, Ankara, Turkey).

Kesen, N. F., Deniz, M. E., \& Durmusoglu, N. (2007). Ergenlerde saldirganlik ve ofke duzeyleri arasindaki iliski: Yetistirme yurtlari uzerinde bir arastirma (The relationship between aggression and ofke levels in adolescents: A research on the development dormitories). Selçuk University, The Journal of Institute of Social Sciences, 17, 353-364.

Keskin, C. (2015). Liseler Arası Müsabakalara Katılan Sporcu Öğrencilerin Saldırganlık Durumlarının Araştırllması[Zonguldak-Kozlu örneği].[Investigation of aggression status of athletes participating in high school competitions].[Zonguldak-Kozlu case]. (Master thesis, Dumlupınar University, Kütahya, Turkey).

Kiper, İ. (1984). Saldırganlık Türlerinin Çeşitli Ekonomik, Sosyal ve Akademik Değişkenlerle İlişkisi[The relationship of aggression types with various economic, social and academic variables] (Master thesis, Ankara University, Ankara, Turkey).

Koçkar, M. T. (1990). Dansın iletişimsel işlevi. Kurgu Anadolu Üniversitesi İletişim Bilimleri Fakültesi 
Uluslararası Hakemli Iletişim Dergisi, 8(8), 327-339.

Küçükkaragöz, H., Canbulat, T., \& Akay, Y. (2013). Öğretmen Adaylarında Atılganlık Düzeyi ve İletişim Becerileri/Assertiveness Level and Communication Skills of Teachers' Candidates. Mustafa Kemal Üniversitesi Sosyal Bilimler Enstitüsü Dergisi, 10(22), 123-133.

McCutchen, B. P. (2006). Teaching Dance as Art in Education. Human Kinetics.

Parasiz, G., (2009). A work directed towards determınıng contemporary turkish music works which are used in educational- music- centered violın teachıng. Ataturk University, Journal of Fine Arts, 15, 19-24.

Petrides, K. V., \& Furnham, A. (2000). Gender differences in measured and self-estimated trait emotional intelligence. Sex roles, 42(5-6), 449-461. https://doi.org/10.1023/A:1007006523133

Rainey, D. W. (1984). A Gender Difference in Acceptance of Sport Aggression. Journal of Teaching of Psychology, 13(2), 138-140. https://doi.org/10.1207/s15328023top1303_9

Salovey, P., \& Mayer, J. D. (1990). Emotional intelligence. Imagination, cognition and personality, 9(3), 185-211. https://doi.org/10.2190/DUGG-P24E-52WK-6CDG

Say, A. (2001). Müziğin Kitabı (1. Basım, p. 122). Ankara: Müzik Ansiklopedisi Yayınları.

Schutte, N., S., Malouff, J. M., Hall, L. E., Haggerty, D. J., Cooper, J. T., Golden, C. J., \& Dornheim, L. (1998). Development and validation of a measure of emotional intelligence. Personality and Individual Differences, 25, 167-177. https://doi.org/10.1016/S0191-8869(98)00001-4

Şenyüzlü, E. (2013). Analysis of the effects of sports participation on aggressive behaviour among University students (Master thesis, Dumlupınar University, Kütahya, Turkey).

Tatar, A., Tok, S., \& Saltukoğlu, G. (2011). Adaptation of the revised schutte emotional intelligence scale into Turkish and examination of its psychometric properties. Klinik Psikofarmakoloji Bülteni-Bulletin of Clinical Psychopharmacology, 21(4), 325-338. https://doi.org/10.5455/bcp.20110624015920

Tekin, A., Tekin, G., \& Eliöz, M. (2011). Examınıng the aggressıveness and anger levels of kıck-boxers considerıng some varıables. Turkish Kickboxing Federation Sports Sciences Journal, 4(1), 34-48.

Tiryaki, Ş. (2000). Spor Psikolojisi: Kavramlar, Kuramlar ve Uygulama. Ankara: Eylül Kitap ve Yayınevi.

Tok, S. (2008). Performans Sporcusu ve Spor Yapmayan Üniversite Öğrencilerinde Duygusal Zekâ İle Kişilik Özelliklerinin Karşılaş̧tırlması [Comparıson of emotıonal intelligences and personality characteristıcs in college student athletes and non-athletes] (Doctoral thesis, Ege University, İzmir, Turkey).

Tutkun, E., Güner, B. Ç., Ağaoğlu, S. A., \& Soslu, R. (2010). Evaluatıon of Aggression Levels Of Indıviduals Participatıng In Team and Individual Sports. Journal of Sports and Performance Researches, 1(1), 23-29.

Uçan, A. (1994), Müzik Eğitimi. Ankara: Müzik Ansiklopedisi Yayınları..

Yaşar, Ö. (2017). Traınıng of Gypsies In The Vicious Circle of Non Educatıon Spırals. Journal of Socıal and Humanities Sclences Research, 4(12), 1241-1253. https://doi.org/10.26450/jshsr.208

Yiğit, Ş. M., Ramazanoğlu, F., \& Kavas, E. (2017). An Examınatıon of Levels of Assertıveness In Students Who Do Sport In Different Branches In University. The Journal of Academic Social Science, 5(60), 353-361. Retrieved from http://www.asosjournal.com/Anasayfa.Aspx

Yılmaz, M., \& Şahin, Ş. (2004). Okul öncesi öğretmen adaylarının duygusal zeka düzeylerinin çeşitli değişkenlere göre incelenmesi. XII. Ulusal Eğitim Bilimleri Kurultayl. Malatya. Retrieved from https://www.pegem.net/dosyalar/dokuman/155.pdf

\section{Copyrights}

Copyright for this article is retained by the author(s), with first publication rights granted to the journal.

This is an open-access article distributed under the terms and conditions of the Creative Commons Attribution license (http://creativecommons.org/licenses/by/4.0/). 